\section{Doctors' Telephones}

SIR,-In the Supplement of February 25 (p. 63) the Post Office states that diversion of calls to an official message bureau would be impracticable "because the bureau could not tell the caller when the doctor can attend." It may be of interest and helpful to your readers to know that as an unofficial bureau we find no difficulty in this respect.

As far as London is concerned, Finders is the largest central message bureau for doctors, and normally, as the name suggests, we really do find the doctors. On one occasion we persuaded the police to intercept a doctor's car-to the doctor's entire satisfaction. On another we induced the stewards at Wimbledon to extract an anaesthetist from the Centre Court. It is true that doctors or secretaries have been known to rush out without saying when they will be back ; but mostly we are told $(a)$ when a doctor will be back, and $(b)$ where he can be found meanwhile, or $(c)$ what other doctor can be called upon in an emergency. In addition, while they are actually out, the doctors can telephone us at any time at Welbeck 6655 to learn who has been asking for them.

We can also make arrangements in certain districts for direct line extensions from the doctor to the bureau. We agree with the Post Office that doctors may be well advised to have an extra entry in the telephone directory. We would only doubt whether even the noblest colleague or chemist can be expected to render a 24-hours-a-day service consistently and promptly all the year round.

There are two final points I hope you will allow me to mention. The first is that in several cases in London doctors have combined to form rosters combining the patients of all, and calls are referred by Welbeck 6655 to the particular doctor on the roster whose turn it is to be on duty. The second point is that I am personally astonished at the number and warmth of the tributes which keep coming in from doctors who have used the service.-I am, etc.,

London, W.1.

\section{Donald H. McCullough,} Chairman, Finders; Lid.

\section{Married Residents}

SIR,-As one of the many married ex-Service students who are now in the "finals" stage, may $I$ draw attention to the dilemma in which we are placed?

We should all like to spend twelve months as junior residents, and would gladly endure the separation from our families as the price of further training. Our wives, too, who have sacrificed much to keep our homes and us going during our student career, will make this further sacrifice in order to see the job well done. But what happens? As soon as we register with the G.M.C. our maintenance grants from the Ministry of Education cease. Instead, as a hard-won concession, we are to receive for six months only a separation allowance at the rate of $£ 20$ a year, with child allowances which, with the family allowance of $5 \mathrm{~s}$. a week for children after the first, add up to $£ 40$ a year for each child. We become liable, however, for National Insurance contributions, superannuation, and incometax-if there is anything left to tax.

We do not dispute that the salaries paid to junior residents are fair and reasonable for the young and single. But for all who are in our position the withdrawal of support from the Ministry of Education means in effect that we are allowed $£ 10$ with which to maintain our wives in a separate home for six months, with a further $£ 20$ for this period for each child. If we wish to undertake a second period of hospital residence, even this meagre allowance goes.

With reforms in medical education foreshadowed in the King's speech, it is believed that a year's residence in hospital after qualification will be compulsory. It seems a pity that those of us who would wish to undergo this further period of training voluntarily must instead offer our willing but inexperienced services as assistants in general practice, where at least we shall command a living wage. The situation calls to mind the old adage about spoiling the ship for a ha'porth of tar.I am, etc.,

London, S.W.10.

J. A. RichaRDS.

\section{B.M.A. FILM LIBRARY}

The following films have been purchased for inclusion in the Film Library.

Angina Pectoris. Sound, colour, 84 mins. Author: Dr. Joseph E Riseman.

Acute Inflammation. Silent, monochrome and colour, 16 mins Authors: Drs. Backett, Hansell, and Moller.

The following films have been copied for inclusion in the Film Library.

Ano-Rectal Fistula. Silent, colour, 15 mins. Author: Mr. C. Naunton Morgan.

Congenital Abnormalities of the Urinary Tract. Author: Mr. T. L Chapman.

The following films held by the Library are recommended by their appraisers as being particularly good.

Angina Pectoris. Appraiser : Film Committee.

The Medical Motion Picture. Appraiser: Film Committee.

Thiopentone Sodium and Its Use in Intravenous Anaesthesia Appraiser: Dr. R. Jarman.

Eye Surgery-Removal of Intraocular Foreign Bodies. Appraiser : Film Committee.

\section{Association Notices}

\section{Diary of Central Meetings}

APRIL

4 Tues. Joint Committee re Remuneration of National Coal Board Medical Officers, 2 p.m.

4 Tues. War Memorial Committee, 2 p.m.

5 Wed. Council, 10 a.m.

6 Thurs. General Medical Services Committee, 11 a.m.

13 Thurs. Publishing. Subcommittee, 11 a.m.

19 Wed. Remuneration Subcommittee, 10.30 a.m.

19 Wed. Special Committee for Spa Practice Report, 2 p.m

19 Wed. Subcommittee re Industrial Dermatitis, 2 p.m.

21 Fri. Drafting Subcommittee, 2 p.m.

MaY

3 Wed. Private Practice Committee, 2 p.m.

\section{Branch and Division Meetings to be Held}

Guildford Division.-At Farnham Hospital, Thursday, April 6. 7.30 p.m., clinical meeting.

North Middlesex Division.-At North Middlesex Hospital, Edmonton, N., Tuesday, April 4, 9 p.m., Medical Film: "Angina Pectoris" (sound and colour).

ScunthorPe Division.-At Royal Hotel, Scunthorpe, Wednesday, April 5, 8.30 p.m., Mr. V. P. McAllister:" The Value of Vagotomy in the Treatment of Peptic Ulcer."

\section{Meetings of Branches and Divisions}

\section{North-EAST EsSEX Division}

A combined meeting and dinner of the Colchester Medical Society and the North-east Essex Division was held at Colchester on March 9. The president of the Medical Society, Dr. J G. Madden, of Tollesbury, took the chair for the dinner. Mr. Green reported that the Zwolle branch of the Dutch Medical Society had again invited members of the Colchester Medical Society to visit Holland, and outlined the proposed programme, consisting of both clinical and social events.

Dr. Charles J. Fox, of Clacton, chairman of the Division, then introduced the speaker for the evening, Mr. Geoffrey Keynes, who gave a B.M.A. lecture on the surgical trealment of myasthenia gravis illustrated with lantern slides and a remarkably fine colour film of the operation of thymectomy. It was much appreciated, as shown by the subsequent questions and discussion. Dr. J. M. Pirrie, of Maldon, proposed a vote of thanks to the lecturer.

Correction.-Discussing the dental service in his letter headed "Cost of the Health Service" in the Supplement of March 25 (p. 103), Dr. Arnold Harbour said: "There seems to be an unanswerable case here of a grant-in-aid from public funds for dental treatment for those who, not liking utility dentistry, find the high fees charged by non-Service dentists beyond their reach." The following sentence said that abuse of this should surely be quite easy. It should have read: "Abuse of this should surely be quite easily prevented." 